\title{
Association between blood Pressure, waist circumference, cholesterolaemia and triglyceridaemia in a population of Cameroonian adults
}

\author{
*Ngoufack JOT. ${ }^{1,2}$, Olivier Pancha Mbouemboue ${ }^{1,3}$, Sakinatou I. ${ }^{1}$, Velinga AC. ${ }^{1}$, \\ Tamanji TM. ${ }^{4,5}$, Koona Koona JA. ${ }^{2}$
}

\begin{abstract}
Objective: Blood pressure (BP) is one of the main cardiovascular risk indicators, but studies on its relationship with waist circumference, triglycerides and cholesterol are rare in low and middle income countries and even non-existent in some areas like the north of Cameroon. The aim of our study was to determine the associations between blood pressure parameters and age, waist circumference, triglycerides and total cholesterol in a north Cameroonian adult population.
\end{abstract}

Method: A cross sectional community-based study was carried out in Ngaoundere (Adamawa region, Cameroon) from June to August 2015. Participants aged 20 years and above were recruited using a multistage sampling technique. Sociodemographic, clinical and biological data were collected and analysed using Microsoft Excel $2013^{\circledR}$ and SPSS version $20.0^{\circledR}$ softwares.

Results: In total 948 participants met our selection criteria. The prevalence of prehypertension (PreHTN), Stage 1 hypertension (HTN) and Stage 2 HTN were $37.55 \%, 26.48 \%$ and $18.57 \%$ respectively. The prevalence of Stage $2 \mathrm{HTN}$ was found to rise with age, waist circumference, serum triglycerides and cholesterol levels. The mean values of systolic blood pressure (SBP), diastolic blood pressure (DBP), pulse pressure (PP) and mean arterial pressure (MAP) were $131.27 \pm 24.07 \mathrm{mmHg}, 86.56 \pm 14.45 \mathrm{mmHg}$, $44.71 \pm 15.45 \mathrm{mmHg}$ and $101 \pm 16.72 \mathrm{mmHg}$ respectively. BP parameters correlated positively and significantly with age, waist circumference, triglycerides and total cholesterol $(\mathrm{P}<0.001)$.

Conclusion: This study demonstrates a positive correlation of blood pressure parameters with age, abdominal obesity, hypertriglyceridemia, hypercholesterolemia, thus the need for stakeholders to strengthen measures towards cardiovascular risk awareness and cardiovascular diseases (CVD) prevention in the general population.

Keywords: Blood pressure, pulse pressure, age, waist circumference, triglycerides, total cholesterol.

*Correspondence author: Jacques Olivier Tsougmo Ngoufack, Email: ngoufacktsougmo@yahoo.fr, ngoufacktsougmo@gmail.com

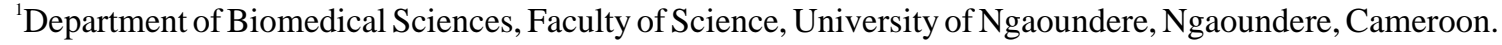

${ }^{2}$ Emergency Service, Ngaoundere Regional Hospital, Ngaoundere, Cameroon.

${ }^{3}$ General Medicine Service, Ngaoundere Regional Hospital, Ngaoundere, Cameroon.

${ }^{4}$ Clinical Laboratory Service, Ngaoundere Regional Hospital, Ngaoundere, Cameroon.

${ }^{5}$ Faculty of Science, University of Buea, Buea, Cameroon.

Research Journal of Health Sciences subscribed to terms and conditions of Open Access publication. Articles are distributed under the terms of Creative Commons Licence (CC BY-NC-ND 4.0). (http://creativecommons.org/licences/by-nc-nd/4.0).

http://dx.doi.org/10.4314/rejhs.v4i4.4 


\title{
Relation entre la pression artérielle, le tour de taille, la cholestérolémie et la triglycéridémie dans une population d'adultes camerounais
}

\author{
*Ngoufack JOT. ${ }^{1,2}$, Olivier Pancha Mbouemboue ${ }^{1,3}$, Sakinatou I. ${ }^{1}$, Velinga AC. ${ }^{1}$, \\ Tamanji TM. ${ }^{4,5}$, Koona Koona JA. ${ }^{2}$
}

\begin{abstract}
Résumé
Contexte : La pression artérielle est connue comme un des principaux indicateurs de risque d'événements cardiovasculaires ou de décès par maladie cardiovasculaire. Cependant, les études s'intéressant à la relation entre la pression artérielle et des paramètres cliniques et biologiques tels que le tour de taille et la lipidémie sont rares dans les pays à revenus faibles et inexistantes dans certaines régions comme le septentrion du Cameroun. L'objectif de notre étude était de préciser la relation entre les composantes de la pression artérielle et l'âge, le périmètre abdominal, les triglycérides et le cholestérol total sériques dans une population d'adultes nord camerounais.
\end{abstract}

Méthode : Nous avons réalisé une étude transversale communautaire dans la ville de Ngaoundéré (Région de l'Adamaoua, Cameroun) de Juin à Aout 2015. Des participants âgés de 20 ans et plus ont été sélectionnés selon un plan d'échantillonnage en grappe. Les données sociodémographiques, cliniques et biologiques ont été collectées et analysées à l'aide des logiciels Microsoft Excel $2013^{\circledR}$ et SPSS $20.0^{\circledR}$.

Résultats: Au total, 948 participants ont répondu à nos critères de sélection. Les prévalences de la préhypertension, de l'hypertension de grades 1 et 2 étaient respectivement de 37,55\%, 26,48\% et 18,57\%. La prévalence de l'hypertension artérielle grade 2 augmentait avec l'âge, le tour de taille et les taux sériques de triglycérides et de cholestérol total. Les valeurs moyennes des pressions artérielles systolique, diastolique, pulsée et moyenne étaient respectivement de 131,27 $\pm 24,07 \mathrm{~mm} \mathrm{Hg}, 86,56 \pm 14,45 \mathrm{~mm} \mathrm{Hg}$, $44,71 \pm 15,45 \mathrm{~mm} \mathrm{Hg}$ et $101 \pm 16,72 \mathrm{~mm} \mathrm{Hg}$. Ces composantes de la pression artérielle augmentaient de façon significative avec l'âge, le tour de taille, la triglycéridémie et la cholestérolémie totale $(p<0,001)$.

Conclusion: Les résultats de cette étude indiquent une relation linéaire positive suffisamment forte entre les différents paramètres de la pression artérielle, l'âge, l'obésité abdominale, les triglycérides et le cholestérol sériques, pour justifier la nécessité d'un renforcement de la sensibilisation sur les facteurs de risque cardiovasculaire dans notre population.

Mots clés : Pression Artérielle, Pression pulsée, Age, Périmètre abdominal, triglycéridémie, cholestérolémie totale

*Correspondance auteur: Jacques Olivier Tsougmo Ngoufack, Email: ngoufacktsougmo@yahoo.fr, ngoufacktsougmo@gmail.com

'Department of Biomedical Sciences, Faculty of Science, University of Ngaoundere, Ngaoundere, Cameroon.

${ }^{2}$ Emergency Service, Ngaoundere Regional Hospital, Ngaoundere, Cameroon.

${ }^{3}$ General Medicine Service, Ngaoundere Regional Hospital, Ngaoundere, Cameroon.

${ }^{4}$ Clinical Laboratory Service, Ngaoundere Regional Hospital, Ngaoundere, Cameroon.

${ }^{5}$ Faculty of Science, University of Buea, Buea, Cameroon. 


\section{INTRODUCTION}

Blood pressure is an important indicator of cardiovascular risk assessment. Its relationship with the risk of major cardiovascular events or death from cardiovascular disease (CVD) has been well known for many years (13). Previous studies report that not only do individuals with cardiovascular disease present with high blood pressure, but also severally with elevated blood cholesterol, triglycerides, and body fat (4). Although increasing blood pressure (BP) is often cited as the most common CVD risk factor, several authors hold that its various components systolic BP, diastolic BP, pulse pressure (PP) and mean arterial pressure (MAP) also constitute cardiovascular risk indicators even when considered independently (3-10).

Studies examining the relationship between blood pressure and other CVD risk factors such as waist circumference, triglycerides and cholesterol are rare in low and middle income countries. For example, to the best of our search, no data on the associations and interactions between BP, triglyceridaemia and cholesterolaemia in the northern regions of Cameroon exist although high hypertension prevalence have been reported in previous hospital-based studies (10-13).

The aim of our study was to independently examine the relationships between blood pressure parameters and age, waist circumference, serum triglycerides and total cholesterol in an adult population residing in northern Cameroon.

\section{MATERIALS AND METHODS Target Population and Selection Criteria}

This study was carried out within the communities of Ngaoundere town and its environs, and included adults of at least 20 years of age and resident within the region for at least a year. Individuals Received information on the aim, merits and demerits of this study prior to a written consent to participate. Persons on corticosteroid therapy, hormonal contraceptives or previously diagnosed with renal disease, cancer or in any state of confounding infirmity such as anaemia, fever, jaundice haemorrhage, dehydration, malnutrition were not included in this work. A visual assessment of participants including skin elasticity, cornea colouration, and body temperature were used to exclude for possible anaemia, jaundice, dehydration, malnutrition and fever.

\section{Sampling Method}

Participants were selected using a multistage sampling technique beginning with the socioeconomic stratification of the different quarters within Ngaoundere into two categories thus: low class and middle-to-upper class. Following stratification, quarters (clusters) were randomly selected within the different socioeconomic strata. In total, we identified and stratified 62 quarters from which 15 were randomly selected with at least one quarter chosen from each of the three subdivisions that make up the Ngaoundere town. Subsequently within every selected quarter one out of every eight living homes was systematically enrolled (beginning with the home of the quarter head) within which one person per home was randomly selected. The total number of homes systematically recruited per quarter varied from 65 to 80 . Prior to the commencement of data and sample collection the, quarter(s) of interest were sensitised a week earlier by means of press releases from the health district and health area heads, local radio stations, community relay agents and customary messengers.

\section{Studied Variables}

Sociodemographic characteristics included gender and age, while clinical variables of interest comprised of blood pressure and pulse rate and waist circumference. Serum triglycerides and total cholesterol constituted biological variables.

\section{Data and Specimen Collection}

Sociodemographic data were collected using a semi-structured questionnaire. Clinical and biological parameters were measured in all participants who met our selection criteria. Selection of participating homes and individuals was done in the evening hours of the day and questionnaires filled by interviewers. Subsequently, instruction for an overnight 8 to 12 hour fast was given in preparation for the collection of fasting whole blood samples and clinical parameters the following morning. Blood samples were collected by venepuncture into dry vacutainer tubes following standard procedures (14), left to clot and transported on ice packs to the laboratory for serum separation (centrifugation) and storage in Eppendorf tubes at $-20^{\circ} \mathrm{C}$ prior to weekly badge analysis.

\section{Measurement of Clinical Parameters}

Blood pressure was measured using an 
electronic sphygmomanometer (BPOmron ${ }^{\circledR} 785$ ) according to the recommendations of The Seventh Report of the Joint National Committee on Prevention, Detection, Evaluation, and Treatment of High Blood Pressure (JNC7) (2).

The waist circumference was measured with a tape (tape Gulickmeasuring ${ }^{\odot}$ ) graduated to an accuracy of $0.1 \mathrm{~cm}$, flexible but not extensible, following the World Health Organization STEPwise approach to noncommunicable disease risk factor surveillance (WHO STEPS) (15).

\section{Measurement of Biological Parameters}

Determination of serum triglycerides and total cholesterol levels were done at the clinical laboratory Service of the Ngaoundere Regional Hospital using commercially acquired kits (Triglyceride PAP, Ref/Lot: TG63000041, Immesco laboratories, Germany and Cholesterol-Liquizyme CHOD-PAP Ref/Lot: 230006, Spectrum diagnostics, Egypt) adapted for semi-automated spectrophotometric analysis and following standard procedures as detailly described in a previous work (16).

\section{Quality Assurance}

Standard specimen collection, processing, storage, transport procedures, and the use of appropriate glass and plastic ware were ensured. Calibration of the spectrophotometer was done by the use of the CALIMAT multiparameter calibrator (Reference: 62321, Lot: 1003001280, Biomérieux, France). Blood pressure measurements for the first 20 participants were measured using both an automated BP monitor and a manual sphygmomanometer. In the same line, the reproducibility of results of fasting serum triglyceride and total cholesterol measurements for these initial 20 samples was assessed using a second semi-automated spectrophotometer (SECOMAM Basic/70V B0358, SN: 1790). Furthermore, analytical quality and validation of results of biochemical measurements was carried out using the LYOTROL $^{\mathrm{TM}} \mathrm{N}$ control serum (Reference: 62373, Lot: 1003001280 , Biomérieux, France).

\section{Ethical Considerations}

Information on the aim, merits and demerits of this study was fully disclosed to the participants in the language best understood by them prior to obtaining a written consent and enrolment into the study. Participation was voluntary and the will to discontinue participation was free and without sanctions. Above all, participants' information was kept strictly confidential, and those with abnormal results were referred to a cardiologist. Ethical and administrative clearances were obtained from the ethical committee of the Ngaoundere regional $\mathrm{h}$ o s p i t a l ( $\mathrm{R}$ e f : 1121/L/RC/RA/DSP/HR/NGD/CLE) and the regional delegation of public health (Ref: 651/L/RA/DSP/SAGE/BPF/NGD) respectively.

\section{Data Analysis}

Data were collected, cleaned, coded and analysed using Microsoft Excel $2013^{\circledR}$ and SPSS $20.0^{\circledR}$ softwares. Mean values, standard deviations and proportions were calculated. The Chi-square test was used to compare frequencies of study variables between men and women. The ANOVA and Kruskal-Wallis test were used to compare means of variables between groups and the Pearson correlation test to investigate any existing relationship between blood pressure markers and clinical and biological parameters. Results were considered statistically significant at $\mathrm{p}<0.05$.

\section{Operational Definitions of Variables}

Pulse pressure (differential pressure) was defined as the difference between the SBP and DBP (3).

Mean arterial blood pressure was defined as the sum of one third of SBP and two thirds of DBP (3).

Abdominal obesity was defined according to the criteria of the Third Report of the National Cholesterol Education Program Expert Panel on Detection, Evaluation, and Treatment of High Blood Cholesterol in Adults (NCEP III), by a waist circumference greater than or equal to 102 $\mathrm{cm}$ in men and $88 \mathrm{~cm}$ in women (17).

Hypercholesterolaemia was defined as serum cholesterol levels greater than $200 \mathrm{mg} / \mathrm{dL}$ (18).

Hypertriglyceridaemia was defined as a serum triglyceride levels greater than $150 \mathrm{mg} / \mathrm{dL}$ (17)

\section{RESULTS}

Blood pressure categories according to JNC7 classification

A total of 948 persons aged 20 to 87 years met our selection criteria. Of these, 464 (48.95\%) 
were male and $484(51.05 \%)$ were women. 165 $(17.41 \%)$ of them presented with an optimal BP (SBP $<120 \mathrm{mmHg}$ and DBP $<80 \mathrm{mmHg}$ ). The overall prevalence of Pre-HTN, Stage $1 \mathrm{HTN}$ and Stage 2 HTN were $37.55 \%, 26.48 \%$ and $18.57 \%$ respectively. In this population, the prevalence of Stage 1 HTN was higher in participants who had a raised serum triglycerides compared to those who had normal serum triglycerides. The prevalence of Stage 2 HTN on the other hand increased with age, waist circumference, and serum triglycerides and cholesterol values (Table 1).

\section{Mean Distribution of Arterial Blood Pressure Parameters}

The mean values of SBP, DBP, PP and MAP were respectively $131.27 \pm 24.08 \mathrm{mmHg}$, $86.56 \pm 14.46 \mathrm{mmHg}, 44.71 \pm 15.46 \mathrm{mmHg}$ and $101.46 \pm 16.72 \mathrm{mmHg}$. The means of SBP, DBP, $\mathrm{PP}$ and MAP demonstrated significant increasing trends when compared between ascending categories of age, waist circumference, triglyceride and cholesterol $(\mathrm{P}<0.01)$, except for mean PP. Likewise, mean PP also portrayed significant increases with increasing age $\mathrm{WC}$ and CT levels, but not with TG levels (Table 2).

\section{Relationship between Blood Pressure and Clinical and Biological Parameters}

The relationship between blood pressure parameters and age, waist circumference, triglycerides and total cholesterol are shown in Table 3.

\section{DISCUSSION}

High blood pressure represents the most frequently encountered CVD risk factors worldwide. In the present study, we set out to examine the association between blood pressure markers and some selected CVD risk factors.

\section{Age}

In this study, we observed a significant positive linear relationship between age and all blood pressure parameters both in men and women. The results of our study are consistent with those of several major observational studies on arterial pressure $(3,19,20)$. According to the Framingham heart study, systolic, diastolic and pulse blood pressures increased with age, although not following an identical pattern (19). It reported that changes in blood pressure as a function of age could be summarised in three phases: firstly, a progressive increase in SBP and DBP up to the age of 50 years marking a predominance of increased vascular resistance; followed by an almost constant DBP contemporary to an asymptotic increase in the MAP coupled with significant elevations in the $\mathrm{PP}$ and a continuous increase in SBP. This second phase depicts an increase in both vascular resistance and stiffness of the large vessels. The third phase characterises a drop in the DBP and a steady increase in SBP, with an increase in PP especially among the elderly (19). Likewise, a cohort study that included 11,150 persons aged 40 to 84 years and on follow-up for 11years in the US showed that before the age of 60 years, SBP and DBP significantly increased with age and after, only SBP continued to increase, while DBP decreased, thus explaining the high prevalence of isolated systolic hypertension in the elderly (3).

\begin{abstract}
Abdominal Obesity
Regarding the waist circumference, and in line with our findings, studies conducted in China (21), Nigeria (22), South Africa (23), Tunisia (24) and the West of Cameroon (25) reported significant positive correlations between SBP, DBP and waist circumference, supporting the notion of abdominal fat accumulation as an indicator of cardiovascular risk (10).
\end{abstract}

\section{Serum Lipids}

Regarding serum lipids, we aimed at screening for raised total cholesterol and triglyceride levels. The prevalence of h y p e r trigly ce rida e mia a n d hypercholesterolaemia were $11.70 \%$ and $51.94 \%$ respectively. Compared with the results of other authors, our results are similar to those of a Senegalese study (26). However, we recorded a wide disparity in the prevalence rates of h y p e r t rigly ce rida e mia a n d hypercholesterolaemia compared with previous literature $(4,18,26-28)$. This disparity in results observed can be attributed to the difference between methodological approaches. For instance, the defining criteria of high cholesterol and the set goals differed between the studies. Furthermore, we found a significant positive correlation between SBP, DBP, MAP and triglycerides one hand, and SBP, DBP, MAP and total cholesterol on the other $(\mathrm{P}<0.01)$. The results of our study are consistent with previous literature data on this aspect $(18,26,28,29)$.

\section{Study Limitations}

The measurement of blood pressure was 
done on a single visit, contrary to international recommendations $(2,30)$, thus a consequent risk of overestimating the average BP level in our study population. Also, laboratory determinations of serum cholesterol and triglycerides were performed once giving the possibility of a white coat effect.

\section{CONCLUSION}

This study shows a positive linear relationship between blood pressure parameters and age, waist circumference, serum triglycerides and total cholesterol. Given these observations, we suggest the improvement of awareness on CVD risk and their associated complications at population level by healthcare stake holders through health promotion sensitisation programs.

Acknowledgments: The authors appreciate the technical support of Ajanta Pharma Ltd, and the collaboration of the Ngaoundere Urban Health District Office, health area heads, heads of selected quarters and community relay agents.

Conflicts of Interests: The authors declare no conflict of interests.

\section{REFERENCES}

1. Haïat R, Leroy G. Facteurs de risque cardiovasculaire : les enseignements des grands essais cliniques. Paris, Editions Frissons-Roche. 2003; 1-224.

2. Chobanian AV, Bakris GL, Black HR, Cushman WC, Green LA, Izzo JL et al. The Seventh Report of the Joint National Committee on Prevention, Detection, Evaluation, and Treatment of High Blood Pressure: the JNC 7 report. JAMA. 2003; 289: 2560-72.

3. Sesso HD, Stampfer MJ, Rosner B, Hennekens CH, Gaziano JM, Manson JE et al. Systolic and Diastolic Blood Pressure, Pulse Pressure, and Mean Arterial Pressure as Predictors of Cardiovascular Disease Risk in Men. Hypertension. 2000; 36: 801-7.

4. Wilson PWF. Lipids and Vascular Disease: A Framingham Perspective. Global Heart. 2013; 8(1): 25-33.

5. Katte J-C, Dzudie A, Sobngwi E, Mbong EN, Fetse GT, KouamKouam C et al. Coincidence of diabetes mellitus and hypertension in a semiurban Cameroonian population: a cross-sectional study. BMC Public Health. 2014, 14: 696.

6. Doulougou B, Kouanda S, Ouédraogo GH, Meda BI, Bado A and Zunzunegui MV. Awareness, treatment, control of hypertension and utilization of health care services following screening in the North central region of Burkina Faso. The Pan African Medical Journal. 2014;19: 259.
7. Xu B, Xu Z, Xu X, Cai Q, Xu Y, Prevalence, Awareness, Treatment, and Control of Hypertension Among Residents in Guangdong Province, China, 2004 to 2007. Circ Cardiovasc Qual Outcomes 2013; 6:217-222.

8. Belhachmi H, Ezzouak A, Badidi M, Nazzi M et El Younassi B. La pression pulsée et le risque cardiovasculaire : à propos de 700 sujets hypertendus. Research.fr. 2014;1:1038. D i s p o n i b e s u r http://www.labome.fr/research/Pulse-pressureand-cardiovascular-risk-a-retrospective-studyof-700-patients.html, consulté le 24/12/2015.

9. El-Menyar A, Zubaid M, Almahmeed W et al. Initial hospital pulse pressure and cardiovascular outcomes in acute coronary syndrome. Archives of Cardiovascular Diseases. 2011; 104(8): 43543.

10. Mushengezi1 B and Chillo P. Association between body fat composition and blood pressure level among secondary school adolescents in Dar es Salaam, Tanzania. Pan African Medical Journal. 2014; 19: 327.

11. Pancha OM, Ngoufack JO, Koona KA, M Falmata, Kingue S, Place et Profil Évolutif des Maladies Cardiovasculaires en Milieu Hospitalier Nord Camerounais: Le Cas de L'Hôpital Régional de Ngaoundéré. Health Sciences and Diseases. 2015; 16(1): 1-7.

12. Pancha OM ; Yiagnigni E, Koona KA, Cacko J and Ndobo P. Determinants of hypertension awareness and treatment among patients under cardiology follow up in a Cameroonian Regional Hospital. International Journal of Collaborative Research on Internal Medicine and Public Health. 2012; 4: 1663-72.

13. Pancha OM, Koona KA, Cacko J. Hypertension and classical risk factors in ambulatory patients: A hospital-based study in Adamawa region (Northern Cameroon). International Journal of Medicine and Medical Sciences. 2011; 3(11): 331-336.

14. OMS. Le Manuel de Surveillance STEPS de l'OMS: L'approche STEPwise de l'OMS pour la surveillance des facteurs de risque des maladies chroniques. Genève, Organisation Mondiale de la Santé. $2005: 453$ p.

15. OPTMQ. Prélèvement de sang par ponction veineuse pour fins d'analyse- règles de pratique Sixième edition Ordre professionnel des technologistes médicaux du Québec 281, avenue Laurier Est, Montréal (Québec). En ligne sur www.optmq.org; consulté le 12/06/2015.

16. Pancha OM, Damdam FB and Tamanji MT. Comparison of lipid profiles and 10year cardiovascular disease risk estimates between indigenous northern diabetic and non-diabetic persons in Adamawa region, Cameroon. Journal of Medical and Biomedical Sciences.2015; 4(3): 18-24.

17. Grundy SM., Becker D, Clark LT, Cooper RS, Denke MA, Howard J et al. Third Report of the 
National Cholesterol Education Program (NCEP) Expert Panel on Detection, Evaluation, and Treatment of High Blood Cholesterol in Adults (Adult Treatment Panel III): Final Report. Circulation. 2002; $106(25): 3143$.

18. Sun G-Z, Li Z, Guo L, Zhou Y, Yang H-M and Sun Y-X. High prevalence of dyslipidemia and associated risk factors among rural Chinese adults. Lipids in Health and Disease. 2014, $13: 189 ; 11 \mathrm{p}$.

19. Franklin SS and Irvine WND. Hypertension and Cardiovascular Disease: Contributions of the Framingham Heart Study. Global heart. 2013; 8(1): 49-57.

20. Mozaffarian D, Benjamin EJ, Go AS, Arnett DK, Blaha MJ, Cushman M et al. Heart disease and stroke statistics-2015 update: a report from the American Heart Association. Circulation. 2015; 131: e29-e322.

21. Wang J, Zhang L, Wang F, Liu L, Wang H et al. Prevalence, awareness, treatment, and control of hypertension in China: results from a national survey. American Journal of Hypertension. 2014; 27(11): 1355-61.

22. Mbah BO, Eme PE and Ezeji J. Prevalence and Risk Factors of Hypertension Among MiddleAged Adults in Ahiazu Mbaise Local Government Area, Imo State, Nigeria. International Journal of Basic and Applied Sciences. 2013; 13(01): 26-30.

23. Peer N, Steyn K, Lombard C, Gwebushe N and Levitt N. A High Burden of Hypertension in the Urban Black Population of Cape Town: The Cardiovascular Risk in Black South Africans (CRIBSA) Study. PLoS ONE. 2013, 8(11): e78567.

24. Hammami S, Mehri S, Hajem S, Koubaa N, Frih1 MA, Kammoun S et al. Awareness, treatment and control of hypertension among the elderly living in their home in Tunisia. BMC Cardiovascular Disorders. 2011, 11(65): 1-7.

25. Abu-Saad K, Chetrit A, Eilat-Adar S, Alpert G, Atamna A, Gillon-KerenM et al. Blood Pressure Level and Hypertension Awareness and Control Differ by Marital Status, Sex, and Ethnicity: A Population-Based Study. American Journal of Hypertension. 2014; 27(12): 1511- 20.

26. Doupa D, Seck SM, Dia CA, Diallo FA, Kane MO, Kane A et al. Dyslipidemia, obesity and other cardiovascular risk factors in the adult population in Senegal. Pan African Medical Journal. 2014; 19:181.

27. Veghari G, Sedaghat M, Joshghani H, Niknezad F, Angizeh A, Tazik E et al. Plasma total cholesterol level and some related factors in northern Iranian people. Journal of Natural Science, Biology and Medicine. 2013; 4(2): 35963.

28. Huang Y, Gao L, Xie X and Tan SC. Epidemiology of dyslipidemia in Chinese adults: meta-analysis of prevalence, awareness, treatment, and control. Population Health
Metrics. 2014, 12 (1): 28.

29. Allayee H, De Bruin TW, Dominguez KM, Cheng LSC, Ipp E, Cantor RM et al. Genome Scan for Blood Pressure in Dutch Dyslipidemic Families Reveals Linkage to a Locus on Chromosome 4p. Hypertension 2001; 38:773778.

30. Mancia G, Fagard R, Narkiewicz K, Redón J, Zanchetti A, Bo“ hm M et al. 2013 ESH/ESC Guidelines for the management of arterial hypertension. Journal of Hypertension 2013, 31:1281-1357. 
Table 1: JNC-7 category of blood pressure by age, waist circumference, triglyceridemia and cholesterolemia $(\mathrm{N}=948)$

\begin{tabular}{|c|c|c|c|c|c|}
\hline Variables & & $\begin{array}{l}\text { Normal BP } \\
\text { n }(\%)\end{array}$ & $\begin{array}{l}\text { Pre-HTN } \\
\text { n }(\%)\end{array}$ & $\begin{array}{l}\text { Stage } 1 \text { HTN } \\
\text { n }(\%)\end{array}$ & $\begin{array}{l}\text { Stage } 2 \text { HTN } \\
\text { n }(\%)\end{array}$ \\
\hline Overall & & $165(17.41)$ & $356(37.55)$ & $251(26.48)$ & $176(18.57)$ \\
\hline \multicolumn{6}{|l|}{ Age (years) } \\
\hline & & $98(17.13)$ & $218(38.11)$ & $155(27.10)$ & $101(17.66)$ \\
\hline $40-64$ & & $53(17.61)$ & $112(37.21)$ & $77(25.58)$ & $59(19.60)$ \\
\hline$\geq 65$ & & $14(18.67)$ & $26(34.67)$ & $19(25.33)$ & $16(21.33)$ \\
\hline \multicolumn{6}{|c|}{ Waist circumference $(\mathrm{cm})$} \\
\hline$<80$ & $<94$ & $92(15.65)$ & $239(40.65)$ & $162(27.55)$ & $95(16.16)$ \\
\hline $80-88$ & $94-102$ & $28(17.39)$ & $58(36.02)$ & $44(27.33)$ & $31(19.25)$ \\
\hline$\geq 88$ & $\geq 102$ & $45(22.61)$ & $59(29.65)$ & $45(22.61)$ & $50(25.13)$ \\
\hline \multicolumn{6}{|c|}{ Triglycerides (mg/dL) } \\
\hline$<150$ & & $148(17.98)$ & $315(38.27)$ & $210(25.52)$ & $150(18.23)$ \\
\hline$\geq 150$ & & $15(13.76)$ & $37(33.94)$ & $35(32.11)$ & $22(20.18)$ \\
\hline \multicolumn{6}{|c|}{ Total Cholesterol (mg/dL) } \\
\hline$<200$ & & $72(16.07)$ & $174(38.84)$ & $128(28.57)$ & $74(16.52)$ \\
\hline$\geq 200$ & & $91(18.80)$ & $178(36.78)$ & $117(24.17)$ & $98(20.25)$ \\
\hline
\end{tabular}

BP: Blood Pressure. HTN: hypertension. Pre-HTN: prehypertension.

Table 2: Comparison of mean blood pressure parameters between age, waist circumference, triglyceride and total cholesterol categories

\begin{tabular}{|c|c|c|c|c|c|}
\hline \multirow{2}{*}{\multicolumn{2}{|c|}{ Variables }} & SBP & DBP & PP & MAP \\
\hline & & Mean (SD) & Mean (SD) & Mean (SD) & Mean (SD) \\
\hline \multicolumn{2}{|c|}{ Total Population } & $131.27(24.08)$ & $86.56(14.46)$ & $44.71(15.46)$ & $101.46(16.72)$ \\
\hline \multicolumn{6}{|c|}{ Age (years) } \\
\hline \multicolumn{2}{|c|}{$20-39$} & $123.93(15.85)^{* *}$ & $83.58(11.39)^{* *}$ & $40.36(10.64)^{* *}$ & $97.03(12.05)^{* *}$ \\
\hline \multicolumn{2}{|l|}{$40-64$} & $140.14(28.95)$ & $90.87(17.08)$ & $49.27(17.77)$ & $107.29(20.09)$ \\
\hline \multicolumn{2}{|l|}{$\geq 65$} & $151.59(30.44)$ & $92.04(17.73)$ & $59.55(21.20)$ & $111.89(20.46)$ \\
\hline \multicolumn{6}{|c|}{ Waist circumference $(\mathrm{cm})$} \\
\hline \multicolumn{6}{|c|}{ Women Men } \\
\hline$<80$ & $<94$ & $128.54(22.47)^{* *}$ & $84.95(13.75)^{* *}$ & $43.59(14.65)^{* *}$ & $99.48(15.70)^{* *}$ \\
\hline $80-88$ & $94-102$ & $132.03(24.88)$ & $87.78(14.90)$ & $44.25(16.12)$ & $102.53(17.22)$ \\
\hline$\geq 88$ & $\geq 102$ & $138.71(26.40)$ & $90.33(15.37)$ & $48.38(16.69)$ & $106.46(18.11)$ \\
\hline \multicolumn{6}{|c|}{ Triglycerides (mg/dL) } \\
\hline \multicolumn{2}{|c|}{$<150$} & $129.92(23.50)^{* *}$ & $85.46(14.06)^{* *}$ & $44.46(15.20)^{\mathrm{NS}}$ & $100.28(16.26)^{* *}$ \\
\hline \multicolumn{2}{|l|}{$\geq 150$} & $142.39(26.64)$ & $95.25(15.13)$ & $47.14(17.25)$ & $110.96(17.97)$ \\
\hline \multicolumn{6}{|c|}{ Total Cholesterol (mg/dL) } \\
\hline \multicolumn{2}{|l|}{$<200$} & $127.19(21.08)^{* *}$ & $83.96(12.77)^{* *}$ & $43.23(14.33)^{*}$ & $98.37(14.53)^{* *}$ \\
\hline \multicolumn{2}{|l|}{$\geq 200$} & $135.26(26.21)$ & $89.06(15.59)$ & $46.20(16.34)$ & $104.46(18.21)$ \\
\hline
\end{tabular}

SBP: Systolic Blood Pressure, DBP: Diastolic Blood Pressure, PP: Pulse Pressure, MAP: Mean Arterial Pressure; SD: standard deviation; NS: not significant; *: $\mathrm{P}<0.05 ; * *: \mathrm{P}<0.01$. 
Table 3: Correlation between blood pressure parameters and age, waist circumference, triglyceride and total cholesterol levels according to gender.

\begin{tabular}{|c|c|c|c|c|}
\hline Variables & PAS & PAD & PP & PAM \\
\hline \multicolumn{5}{|l|}{ Males } \\
\hline Age & $0.44 * *$ & $0.29 * *$ & $0.40 * *$ & $0.38 * *$ \\
\hline Waist circumference & $0.22 * *$ & $0.20 * *$ & $0.15^{\mathrm{NS}}$ & $0.22 * *$ \\
\hline Triglycerides & $0.20 * *$ & $0.24 * *$ & $0.09^{\mathrm{NS}}$ & $0.24 * *$ \\
\hline Total cholesterol & $0.20 * *$ & $0.21 * *$ & $0.13 * *$ & $0.22 * *$ \\
\hline \multicolumn{5}{|l|}{ Females } \\
\hline Age & $0.43 * *$ & $0.29 * *$ & $0.40 * *$ & $0.38 * *$ \\
\hline Waist circumference & $0.22 * *$ & $0.20 * *$ & $0.15 * *$ & $0.22 * *$ \\
\hline Triglycerides & $0.20 * *$ & $0.24 * *$ & $0.09^{\mathrm{NS}}$ & $0.24 * *$ \\
\hline Total cholesterol & $0.20 * *$ & $0.21 * *$ & $0.13 * *$ & $0.22 * *$ \\
\hline \multicolumn{5}{|l|}{ Total } \\
\hline Age & $0.44 * *$ & $0.29 * *$ & $0.40 * *$ & $0.38 * *$ \\
\hline Waist circumference & $0.22 * *$ & $0.20 * *$ & $0.15 * *$ & $0.22 * *$ \\
\hline Triglycerides & $0.16 * *$ & $0.24 * *$ & $0.09 * *$ & $0.24 * *$ \\
\hline Total cholesterol & $0.18 * *$ & $0.21 * *$ & $0.13 * *$ & $0.22 * *$ \\
\hline
\end{tabular}

NS: not significant; *: P<0.05; **: $\mathrm{P}<0.01$; SBP: Systolic Blood Pressure, DBP: Diastolic Blood Pressure, PP: Pulse Pressure, MAP: Mean Arterial Pressure. 